\title{
Brand-name drug costs expected to rise under CETA
}

Cite as: CMAJ 2017 January 16;189:E84-5. doi: 10.1503/cmaj.109-5363

$\mathrm{N}$ ew brand-name pharmaceuticals are projected to cost roughly $6.2 \%$ more in the long run, at an estimated cost of $\$ 850$ million a year for Canadians, if the proposed Canada-European Union Comprehensive Economic and Trade Agreement (CETA) comes into effect.

CETA has been signed, but awaits ratification by Canadian and European Parliaments. If Bill C-30 is ratified, the government will then need to develop implementation regulations.

Several CETA provisions are causing concern among pharma watchers. The Canadian Centre for Policy Alternatives, an independent research institute, points to two clauses in particular. Patent term restoration will extend patents for brand-name drugs by two years, and brand-name pharmaceutical companies will have the right to appeal court decisions on patent validity. These two measures will extend the period of monopoly protection for higher-cost brand-name pharmaceuticals in Canada and delay the availability of cheaper generic drugs on the market, Scott Sinclair, director of the centre's Trade and Investment Research Project, said in an email.

"CETA's new pharmaceutical rules are predicted to increase Canadian drug costs by at least $\$ 850$ million annually - approximately $7 \%$ of current spending on patented drugs - once they are fully in effect," says Sinclair.

The former Conservative federal government promised to compensate provincial governments for the increased cost to their public drug programs. But that won't help people whose private insurance premiums increase, or who pay out of pocket, says pharma expert Dr. Joel Lexchin, professor emeritus at York University's School of Health Policy Management in Toronto. "Basically a lot of people who fall into this are the working poor," he says. "It could have very serious consequences for their ability to access medications." These people will pay twice: through increased taxes and increased costs for drugs.

Canada is now the third top payer for pharmaceutical products on a per-capita basis at $\$ 713$ US per year/person, behind only the United States and Japan. Organisation for Economic Co-operation and Development nations average \$515; Denmark comes in at $\$ 240$.

"We're spending three times per person per year what Denmark spends," says Lexchin. "You don't find bodies lying on the street in Copenhagen."

Should Canada ratify CETA? "Strictly on the basis of the pharma clauses, no," says Lexchin. "We're not getting anything in return for signing it."

The cost of patented drugs is projected to rise by $\$ 850$ million under CETA.

\section{Patent term restoration}

This CETA provision allows brand-name drug companies to extend their patents by up to two years to compensate for the time Health Canada spends approving their drugs. Patent term restoration delays entry of generic medicines by those two years, says Lexchin. His 2014 paper in the Journal of Global Health estimates this prolonged patent period will mean drugs approved after CETA take effect will cost $6.2 \%$ more in seven or eight years, when patents on these new drugs expire.

"It's a rough guess, but I would say it's still accurate," Lexchin says.

Innovative Medicines Canada, the brand-name pharmaceutical company's trade organization, defends the move, pointing out that Canada is the only G7 nation without patent term restoration. 
Furthermore, most countries allow restoration of up to five years, not two, says Declan Hamill, vice-president of legal and regulatory affairs and policy. "It's a step in the right direction, although we'd ideally like to see Canada at the same level as its major trading partners."

\section{New right of appeal}

CETA also provides a right of appeal to brand-name drug companies in court challenges on their patents. This could delay the approval process for generic drugs by potentially more than six months, according to Marc-André Gagnon, Lexchin's coauthor on the 2014 paper and an associate professor in the School of Public Policy and Administration at Carleton University in Ottawa.

Patent linkage regulations require generic manufacturers to show that patents on brand-name products have expired. If the patent holder disagrees, it can apply to the Federal Court of Canada to prohibit marketing the generic product for up to two years. The stay on the generic expires either at the end of two years when the disputed patent expires or when the court case is decided, whichever comes first.

Brand-name companies cannot currently appeal the federal court's decision, but under CETA they will gain this right.

The brand-name companies support this, says Hamill. "We feel that's just a matter of common-sense equity that doesn't disadvantage either party." These provisions are not actually in CETA; they will be set out in regulations if Bill C-30 passes.

Gagnon finds this appeal provision "weird." European countries do not allow patent linkage regulations because they are considered to be too strong a barrier to generic entry to market, yet CETA requires Canada to beef up these very regulations, says Gagnon. He notes that the United States drug lobby has been calling for a similar right of appeal for years.

The Canadian Generic Pharmaceutical Association President Jim Keon would not comment on this change, noting instead that the government has "committed to do more than just add a right of appeal."

Keon says the generic association has been working with Innovation, Science and Economic Development Canada (for- merly Industry Canada), on regulations that do away with the current dual litigation system. Currently, there is litigation under the patent linkage regulations, and, after that concludes, the right for either party to start a new action. This latter right, Keon says, will be eliminated. "It has led to massive amounts of litigation and costs and uncertainty in the system."

\section{Increased compensation}

In addition, the generics are negotiating with government regulators to increase compensation for the automatic two-year stay on generics if, in the end, the patentholder's claim that its patent is still valid proves to be false.

"What we've insisted is that government needs to put a system in place that allows a generic to seek proper damages if it's held off market," says Keon. Current damages can be around 15\%-20\% of brand-name sales, reflecting the lower price of the generic. Manufacturing and marketing costs are also subtracted. "They just put in so many restrictions, that the amount of money available for damages is generally much smaller than the loss of competitive revenue that the companies are facing," says Keon.

"We're saying we need damages, otherwise there's little or no business incentive to challenge these patents and bring the product to market," adds Keon. Increased compensation would also deter brand-names from proceeding with challenges, he says.

However, ending dual litigation and increasing compensation are not written into CETA; these too would have to be introduced in regulations.

"We believe the changes will be coming, but I don't know that for a fact," says Keon. "If those changes aren't made, you are going to see significantly fewer generic challenges of patents, which means it will be longer and longer before we have generic competitors coming to market, and increased cost to payers."

Hamill at Innovative Medicines Canada says if generics can demonstrate lost market share, then compensation is okay. But, he adds, "We're not in favour of a system which is punitive as opposed to compensatory."

Hamill says he's concerned the government may introduce other regulations that prolong litigation. "The devil is in the regulations," he says.

Keon says he too is taking a wait-andsee attitude.

\section{Investor-state dispute}

Other aspects of CETA may also cost Canada. A case in point is a provision that would allow drug companies to sue Canada using a legal mechanism known as investor-state dispute settlement (ISDS), which relies on three-member arbitration tribunals rather than domestic courts.

Precedents are starting to demonstrate that this could be very expensive for Canadian taxpayers. Using ISDS provisions in the North American Free Trade Agreement, Eli Lilly sued Canada for $\$ 500$ million in June 2013 over court rulings invalidating patents on drugs for schizophrenia and hyperactivity.

"These clauses might be reasonable if you thought the court system was subject to political pressures," says Lexchin. "But companies have always had the ability to go through the Canadian court system to challenge things and there's no evidence that the Canadian court systems aren't functioning well."

"I don't really see the need for an ISDS provision," says Lexchin.

The new trade agreement also locks in data exclusivity protection in Canada. There are two potential difficulties with this, says Gagnon. First, it means Canada can't institute less data exclusivity. Second, it's not known whether the exclusivity regulations apply to "new" drugs that are a mix of two or more existing molecules.

"Will that be considered a new active substance? That wasn't clear," says Gagnon.

If the clause is interpreted to mean that these combinations do constitute a new drug, then market exclusivity would be extended and the entry of generics delayed for those products. That means the long-term costs of patent drugs approved after CETA is in place would increase by $12.6 \%$, instead of $6.2 \%$.

"I was surprised at how much data exclusivity is affecting the costs of drugs," says Gagnon. "I thought it would be something marginal."

Barbara Sibbald, CMAJ 